\title{
Planetary carambolage: The evolutionary political economy of technology, nature and work
}

\author{
Katarzyna Gruszka ${ }^{1} \cdot$ Manuel Scholz-Wäckerle $^{2}$ (D) Ernest Aigner $^{3}$
}

Accepted: 16 November 2020 / Published online: 27 November 2020

(C) The Author(s) 2020, corrected publication 2020

\begin{abstract}
The following editorial introduces the special issue (SI) on "Work, Environment and Planetary-scale Computation in Political-Economic Evolution". Here, however, we go beyond an outline of what each contribution to the SI addresses, and attempt to draw a more pronounced shared embedding of the arguments that have come to the fore. The original idea of this SI was to synthesize a range of contemporary global politicaleconomic challenges, i.e. (1) technology (esp. digital transformation), (2) nature (esp. ecological crisis) and (3) work (esp. precarization via the evolving platform economy). The main argument developed in this editorial reflection focuses on the common ground and origin of those processes found in the complex evolution of capitalist development. We frame the latter by assigning it a new term, i.e. "planetary carambolage".
\end{abstract}

Keywords Political economy · Complexity · Evolution · Capitalist development · Ecological crisis $\cdot$ Digital transformation $\cdot$ Platform work

JEL codes $\mathrm{B} 51 \cdot \mathrm{B} 52 \cdot \mathrm{J} 81 \cdot \mathrm{O} 33 \cdot \mathrm{P} 11 \cdot \mathrm{P} 16 \cdot \mathrm{P} 18 \cdot \mathrm{Q} 57$

Manuel Scholz-Wäckerle

manuel.scholz-waeckerle@wu.ac.at

Katarzyna Gruszka

katarzyna.gruszka@wu.ac.at

Ernest Aigner

ernest.aigner@wu.ac.at

1 Institute for Ecological Economics, Department of Socioeconomics, Vienna University of Economics and Business, Wien, Austria

2 Department of Socioeconomics, Vienna University of Economics and Business, Wien, Austria

3 Institute for Economic Geography and GIScience, Department of Socioeconomics, Vienna University of Economics and Business, Wien, Austria 


\section{Introduction}

This editorial introduces the special issue (SI) on "Work, Environment and Planetary-scale Computation in Political-Economic Evolution". In this SI of the Review of Evolutionary Political Economy (REPE), we ask questions about the current state of capitalism and its potential of endogenous transformation to disrupt the phase of what we refer to as planetary carambolage. The call asked for evolutionary political economic approaches synthesizing problems around the automation of production and exchange, the future of work and the implications for the environment. In addition to the summary of the contributions to the SI, this article argues that there is a common ground in the origin of the three crucial contemporary global political economic challenges, more specifically, the challenges of (1) digital transformation, (2) ecological crisis and (3) the precarization of work via the evolving platform economy. This common ground, we argue, is located in the complex evolution of capitalism, its development, the understanding of which can be supported with the concept of planetary carambolage.

The SI begins with Hanappi (2020) explaining the role of "relatively stable configurations in evolving complex systems" for the evolution of political economy in the human species. Complexity and evolutionary theory indicate that capitalist development is not a continuous process of growth. Rather, it can be seen as development which is regularly disrupted by discrete moments of change. These discrete moments depend on novel qualities of the political economy. The emergence of novel qualitiescapable to transform the system into a new stable configuration - is shaped by grouplevel processes, group communication structures and practices. This view complements the contributions by Foley $(2020 \mathrm{a}, \mathrm{b})$, exploring socialist alternatives to capitalist development from a historical perspective. Foley (2020b) discusses the digitalization as a potential source of transforming capitalism through decentralized and selforganized planning and production processes. Schröter (2020) delves deeper into this question by emphasising the notion of "imaginary economy" from a media science perspective. The article explains how such an imaginary- "a collectively held system of more or less vague or detailed ideas, what an economy is, how it works, and how it should be" (ibid.) - contributes to stabilising an economy and how it translates into the transformation of an economy.

While these contributions focus on the long-run perspectives of capitalist development, two more articles in this SI emphasize the short and medium run. Bertani et al. (2020) elaborate on the short- and medium-run effects of the digital transformation on productivity and employment, in an agent-based macroeconomic modelling framework. Still, it is not evident how the rapidly growing energy and resource demand of planetary-scale computation ${ }^{1}$ can be provided in a sustainable way, in terms of social

\footnotetext{
1 "Planetary-scale computation" is a term used by Bratton (2015) to address the geopolitical, international, political-economic dimension of the production, exchange and use of information and communication technology. "Planetary-scale computation takes different forms at different scales - energy and mineral sourcing and grids; subterranean cloud infrastructure; urban software and public service privatisation; massive universal addressing systems; interfaces drawn by the augmentation of the hand, of the eye, or dissolved into objects; users both over-outlined by self-quantification and also exploded by the arrival of legions of sensors, algorithms, and robots. Instead of seeing all of these as a hodgepodge of different species of computing, spinning out on their own at different scales and tempos, we should see them as forming a coherent and interdependent whole." (ibid., pp. 4-5)
} 
cohesion and climate justice. Many consider decoupling economic growth from greenhouse gas emissions via a transition towards renewable energy supply as the solution to the problem, although this remains empirically questionable (Haberl et al. 2020). The contribution by Bettin (2020) sheds light on that transition by revisiting and amending the evolutionary economic theory of innovation systems.

In what follows, we first introduce the concept of planetary carambolage in Section 2 to unravel the complexity and evolution of capitalist development that has led to a collision of exploitation processes across several domains on planetary scale. Section 3 synthesizes the contributions to the SI along planetary carambolage and discusses the endogenous nature of recurring, interdependent and cumulating crises in capitalist development. In Section 4, we first discuss the platform economy as a new political-economic configuration that relies on planetary-scale computation to coordinate a highly specialized global system of value chains depending on resource- and energy-intensive labor exploitation. In Section 5, we contrast the potential of capitalism to stabilize the current regime of accumulation with its potential to transform itself into a novel political-economic configuration. We conclude with arguing that capitalism's innate forces of self-transformation allow for speculation about future crises and more stable forms of configurations beyond capitalism.

\section{Planetary carambolage}

The current stage of capitalist development can be interpreted in terms of a steady process of a crashing world that does not abruptly destroy, but sets everything in a slow and steady collision, and that may tip over into catastrophes. This collision of exploitation processes on planetary scale is what we call planetary carambolage, a perspective that reveals a world of slow degradation and multiple crises that, on its surface, does not look very harmful. Increasing frequency of natural disasters (IPCC 2012), of ecological catastrophes such as biodiversity loss (Butchart et al. 2010), the high number of environmental conflicts (Scheidel et al. 2020) and accelerating exploitation in the context of platform economies are mere symptoms of a global process that is driven by increasing inequalities in political-economic power. Conceptual contributions that emphasize and analyze dynamics of, e.g. monopoly capitalism (Baran and Sweezy 1977) or surveillance capitalism (Zuboff 2019), the expulsion and stabilization of reserve armies (Sassen 2014), and the dominance of fossil fuel corporations ${ }^{2}$ in financial and real economics (Foster 2013) all help to identify driving forces and decisive agents in guiding processes of capital accumulation and the related complex evolution of contemporary capitalism.

Set in relation to the pace of changes in the whole human history, the current world economy is changing drastically. Capital accumulation processes transform the social, aesthetic, political spheres at similar magnitudes as the spatial, environmental and technological. Those changes are happening simultaneously on multiple levels, thus entering the particular level of the subjective self as well as macroscopic levels of spatial development or the planetary biosphere. The human economic code structures

\footnotetext{
2019 top 10 largest companies worldwide by revenue (*oil and gas): Walmart, Sinopec Group*, State Grid, China National Petroleum*, Royal Dutch Shell*, Saudi Aramco*, Volkswagen, BP, Amazon, Toyota.
} 
bits and pieces of all planetary matter and energy, in a seemingly continuous process of reproduction. Still, we know from the world history of capitalist development that the social and economic reproduction is at large not continuous but finds itself always disrupted at the peak of financial expansion (Arrighi and Moore 2001). The financial expansion of the last 40-50 years was very much shaped by pension fund capitalism and the most recent return of state finance capitalism with post-2008 quantitative easing programs (Toporowski 2020). When we ask ourselves about the capitalist enterprises with the highest market capitalization of today, we will find tech companies that have made their gains on behalf of the digital transformation, in particular on behalf of the evolution of the platform economy. ${ }^{3}$

Their actual source of surplus is given by an extended mode of labor exploitation that can be associated with dividuation (Deleuze 1992; Lazaratto 2014). In general, the labor process generates the individuals it needs most for the current social division of labor (Lazaratto 2014, p. 24). However, the digital transformation has led to an ever more automated production with highly specialized global value chains as well as an exchange system working with personalized ads. On a larger scale, the labor process has started to generate "dividuated" workers who are, thus, "no longer instituted as an 'individuated subject', 'economic subject' (human capital, entrepreneur of the self), or 'citizen"' (ibid., p. 25) but as dividuals. This process involves a fragmentation of the single individual worker who is employed in multiple jobs in parallel. This is different to the former more industrial fragmentation of the whole working class into specialized workers. The process of dividuation (i.e. the fragmentation or parallelization of individual labor) gets enforced by the increasing algorithmic governance of production and exchange systems. The labor process no longer focusses on the supply of individualized labor power, but just on a multiplicity of atomized tasks that are then matched with agents. ${ }^{4}$

Reaching this stage of capitalist development was very capital-intensive over the last 40-50 years in terms of machinery but also of software. One of the central questions of planetary carambolage is about the energy source of this capitalist development. In general, this machinery is fueled at large extent by fossil fuels ever since the owners of the means of production in industrial capitalism discovered the advantage of place- and time-independent concentrated forms of energy. The remaining dependence on such forms of energy reveals their advantage compared to renewable, fluctuating and placespecific energy forms. Crucially, this "imbalance" is not necessarily related to the higher degree of energy efficiency or technological superiority of the combustion engine. What lead to the adoption of fossil fuels to drive capital accumulation is their advantage in gaining control of an otherwise dispersed labor force whose work depends on fluctuations in available energy (Malm 2013). Until today, the transformation towards renewable and thus sustainable energy forms faces the grand challenge of meeting the time and place-specific energy demand, under the principles that guide the evolution and complexity of capitalism (ibid.).

The Marxian concept of social-ecological metabolism provides a common ground for the analysis of the planetary carambolage because it connects the three global

\footnotetext{
32020 top 5 capitalized US companies in chronological order: Microsoft, Apple, Amazon, Alphabet, Facebook

${ }^{4}$ See also Eversberg (2014) for this evolution of the labor market, with an empirical investigation of the German labor market.
} 
contemporary challenges we highlight, i.e. technology, nature and work. The concept regards labor process as the main driver of mediation between social and ecological values, i.e. the social-ecological metabolism (Fischer-Kowalski 1998; Foster 1999). Running through many variants in the evolution of humankind, the contemporary social-ecological metabolism becomes a threat to the planet and life through capitalist development (Steffen et al. 2011). As Marx explained, labor is primarily a process of mediation, regulation and control of the metabolism between humans, their actions and nature (Marx 1992, p. 283). The current stage of capitalist development depends on maintenance of place-independent, highly concentrated forms of energy that ensure the stabilization of current capital accumulation. Moreover, it subverts and cleaves the metabolic relations of society and nature through the generation of isolated, dividuated and therefore polarized worker subjectivities. Concurrently, the platform economy has emerged as the main coordinator of a dividuated subjectivity, structuring lives of platform-mediated workers, as we outline in Section 4. However, before we arrive there, we take a deeper look into the contributions to this SI and what they might reveal about planetary carambolage.

\section{Summary and editorial reflections I: formation of the planetary carambolage}

In the following section, we discuss each contribution to the SI as highlighting different aspects of complex and evolutionary unfolding of global development. We start with outlining the role of transpersonal communication, hegemony and stability of capitalism. Next, we discuss the importance of conceptualising economic development as complex adaptive systems that evolve in interdependence with technological change. Furthermore, we give indications that such systems are best analysed with agent-based modelling approaches that provide significant insights in the future of capitalism in the context of digitalization. Congruently, these developments occur in a world of changing energy and material resources, where particularly evolutionary political economy theory can make significant contributions.

Human species is distinct from other species because it is capable of transpersonal communication. It can write and share its own history by using different media. The simplest forms of such media are objects, artefacts or tools, pieces of technology (Hornborg 2016). A simple tool carries a story, an instruction, an institutional code, a set of information or simply some kind of use value through the way how the original matter is transformed into this object. It is the combination of the chosen material and the emergent design that makes it sensible and comprehensive for other humans who have not been original members of the crafting group.

In other words, the human species has been bound to use a shared language to become an enduring social entity. It is the exchange of perception filters, in the communicative capacity of tribes of human individuals, which enables and constitutes individual consciousness. The existence of this second mirror is built on the primacy of the group.

Hanappi (2020) 
Human societies are evolving and complex because they communicate in transpersonal terms via shared languages (Dopfer 2004; Richerson and Boyd 2010). Use values are pivotal to the evolution of societies since they expand the communicative capacity over time and space, thereby enabling humans "to become an enduring social entity" (ibid.). However, use values are also pivotal to the complexity of societies because individual agents never process use values identically; i.e., they are heterogeneous agents and members of diverse groups (within a larger population), with their own internal models (i.e. habits, norms, customs, traditions, social relations of production). These characteristic interpretations of use values are only relatively stable over space and time since complex systems are alien to states of static equilibria. Hanappi (2020) refers in that context to the "primacy of the group" which becomes effective through the use of a shared language and communication and through the emergence of communities. The cohesive development of a community may stabilize a specific configuration of use values and their transpersonal diffusion, thereby building up hegemony.

The significant question for any kind of evolutionary political economy is about the relative stability of that hegemony in space and time. Hegemony establishes a discursive field of power that programs institutions in the interest of the hegemon, with effects for the real economy. ${ }^{5}$ Hanappi (2020) explains that through building up hegemony, a specific discursive mode of communication allows groups and communities to shape their future and the future of others in real terms. Obviously, this has significant effects for the evolution of a political-economic system, foremost for its economic structure and organization. However, this chain of causation may simultaneously run the other direction once the economic sphere invokes changes in the political discursive layer. This circumstance makes the political economy essentially evolving, complex and path-dependent, for it can never reproduce itself through perfect circular copies (Prigogine and Stengers 1997; Georgescu-Roegen 1971). This clarifies that standard economic theory-building primarily upon methodological individualism and the general equilibrium framework - is of limited value in explaining long-run complex, developmental and evolutionary processes such as capitalist development and its future transformations. It is certainly a research field where an interdisciplinary evolutionary political economy approach can make significant contributions (see Hanappi and Scholz-Wäckerle 2017).

The complex evolving interplay between the political sphere of group communication and hegemony and the economic sphere of organizations and institutions of production and exchange highlights that capitalist development does not follow simple top-down causal mechanisms. Rather, it is a diverse, non-linear and multidimensional process. Parts of the heterodox economic tradition have always discussed the transformation of capitalism (Jo et al. 2018, part V). Especially for the Marxian approach, capitalist development has played a major role. However, there have been substantial developments in Marxian theory within the last decades, allowing for a more nuanced understanding of capitalist development and its endogenous transformation (see also Brennan et al. 2017). The significant role of complexity and evolutionary theory is further elaborated in Foley's contributions (2020a/b) to this SI.

\footnotetext{
${ }^{5}$ A good example of the late twentieth century is given by the neoliberal hegemony of the Washington consensus and the institutional programming of development policy by the World Bank and the International Monetary Fund in these days (see, e.g. Fine 2001, part III).
} 
This bottom-up vision of social organization resonates with important political currents of the late twentieth century. The "New Left" movements of the 1960s rebelled against the centralizing and regimenting tendencies of "Old Left" socialism and communism by calling for decentralization, participation, and the political primacy of individual freedom and expression. The Left, such as it is in the contemporary world of globalized capitalism, is much more attracted to the vision of spontaneous political expression than to the unpleasant chore of organizing political and economic institutions.

Foley (2020b)

Foley (2020b) argues that the idea of self-organizations in complex (adaptive) systems, and especially its "bottom-up vision", has transformed the Marxian approach to critical political economy. In his two companion essays, Foley $(2020 \mathrm{a}, \mathrm{b})$ develops "socialist alternatives to capitalism" along a close reading of antagonistic authors such as Marx and Hayek. Where Foley considers Hayek "an important turning point in our conceptualization of social life, leading to regarding human societies as complex, adaptive systems" (Foley 2020a), Hanappi (2020) would rather refer to authors such as John von Neumann and Erwin Schrödinger in that perspective, who have focused a great deal of their work on complexity theory. Both, Foley and Hanappi, develop a strong NeoMarxian understanding of endogenous transformation processes shaped by complexity and evolution. ${ }^{6}$

Furthermore, properties of complex adaptive systems such as emergence, cumulative causation, irreversibility or path-dependency ask for an intentional and interactive theory of agent behavior and decision-making (Elsner 2017). Agents in evolutionary political economy models are able to self-organize, communicate and regulate themselves via institutional coordination and structuration. Such models synthesize the political with the economic via group-level processes on meso-scale (see Dopfer et al. 2004; Elsner and Heinrich 2009; Scholz-Wäckerle 2017). In agent-based models, the emphasis shifts from the general equilibrium approach of standard economic theory to the relative stability of political-economic configurations of evolutionary political economy. In this SI, we feature an agent-based macroeconomic model used for investigating the dynamics of the digital transformation. ${ }^{7}$

Bertani et al. (2020) focus on the economic effects of automation as the "third morphing [of digital revolution] is bringing intelligent machines", 8 especially on employment and productivity. With reference to Arthur (2009), the authors argue that it is not just the accelerating diffusion of "intangible digital technologies" that is disrupting and transforming the current political-economic configuration. They also stress the role of synergistic effects between novel digital technologies, e.g. between automation processes in production and big data-driven machine learning in marketing departments. The empirical part of their study illustrates correlations between intangible investments and labor as well as capital productivity. Data indicates generally that

\footnotetext{
${ }^{6}$ See Wilson (2016) for a contemporary reading about the complementarity of complexity and evolution in multi-level selection processes.

${ }^{7}$ Agent-based macroeconomic models have received increasing attention in the recent literature. Compare for instance a recently published special issue edited by Dosi and Roventini (2019), also featuring a macro ABM with endogenous social class dynamics as discussed previously (Rengs and Scholz-Wäckerle 2019).

${ }^{8}$ Brackets added by the authors.
} 
"capital productivity, measured as the ratio between GDP and capital services has been decreasing in most OECD countries for the past twenty years" (Bertani et al. 2020). However, the authors find significant correlation between the growth in intangible investment and total factor productivity growth, especially for the years 2008-2014. The crucial question for their model is about the drop of labor demand in consumer good producing firms and the potential increase in intangible digital asset developer firms that could compensate the technological unemployment in the long run. The authors posit that the absorptive capacity of labor through the latter compensation mechanism (via digital developer firms) depends substantially on the rate of innovation, the success in research and development. A higher rate of innovation translates directly into higher unemployment rates since the labor market cannot transform quickly enough. Therefore, the model delivers new insights on the transformation of "a mass production economy to a digital service one" (Bertani et al. 2020), elsewhere called "platform capitalism" (Srnicek 2017). Furthermore, resonating with the core question of evolutionary political economy, the model emphasizes the role of the pace of structural change in capitalism.

The production of ever more digital intangible assets may come at different speeds, leading to different hypotheses about structural change. Altogether, it also invites speculation and development of utopian visions around bottom-up aspects of peer production, as envisioned in the idea of "Lifenet" by Foley (2020b), or the idea of open source and the commons for collaborative infrastructures of degrowth (Likavčan and Scholz-Wäckerle 2018), or, in general, in the post-capitalist visions of "A society after money" (Aigner and Scholz-Wäckerle 2019). These latter streams of thought share the development of "imaginaries", as Schröter (2020) elaborates in his article for this SI. The author differentiates between the technical and the social imaginary from the perspective of media science:

Whatever one may think of this concept [ex ante mediation of production quota]: It is a social imaginary, the idea of a (supposedly) possible and desirable other social form. In contrast, a technical imaginary is the idea of a (supposedly) soon possible, world-changing technology.

Schröter $(2020)^{9}$

Where Bertani et al. (2020) focus on the economic implications of a technical imaginary, Foley (2020b) and Schröter (2020) aim to build bridges to the social imaginary. This discussion goes beyond the question of "what is technologically possible/feasible?" but addresses particularly the question of "what kind of society can we even imagine?" Schröter (2020) discusses the 3D printer as a representative case for a typical technical imaginary. The $3 \mathrm{D}$ printer opens a variety of imaginaries, since production can be performed on site and requires no centralized production facility. As outlined by the author, the $3 \mathrm{D}$ printer often acts as a signifier for a more potent manufacturing machine that could also assemble far more complex objects, or basically "just everything". Schröter (2020) points out that an imaginary economy depends on the coevolution of a technical and a social imaginary. Expressed through the lens of media science and the crucial aspect of social mediation, he highlights why the $3 \mathrm{D}$ printer

\footnotetext{
$\overline{{ }^{9}}$ Parenthesis added by the authors.
} 
could be a "problematic" technical imaginary for capitalism and why it inevitably directs towards a post-capitalist utopia. Schröter (2020), by following Marx, argues that capitalist production (on behalf of "separate private production") relies on "ex post mediation between the producers". 10 The most famous antithesis to capitalism (i.e. socialism) builds correspondingly on "ex ante mediation", resting on a social imaginary where production quota are determined in social terms ${ }^{11}$ before the production even begins. However, this imaginary faces other difficulties associated with coordination problems in society and the to-be-negotiated rule systems for the ex-ante mediation process. That is why Schröter (2020) presents the case of the 3D printer as a separate antithesis to capitalism in addition to socialism, where the printer acts as an "ideal fabrication machine" for "omnipotent production". This framing comes with a libertarian flavor because it is "still individual, but no longer merely partial". The central advantage of a social imaginary is that it does not depend on ex-ante mediation because all production is still individual.

Apparently by itself and without the efforts of political enlightenment, discussion, struggle, and even the reshaping of subjectivity, a machine of this kind could overcome the existing form of society. This technical imaginary might be the central reason for the popularity of the $3 \mathrm{D}$ print post-capitalism utopia.

Schröter (2020)

Can a new technology alone invoke major transformations? No, certainly not. Of course, technology enforces group communication, cooperation and mediation processes; it shapes the agents' internal models, their values and norms. It may (de)stabilize the group identity and the power of communities in that spirit. But technological change necessitates social (institutional) change and vice versa, as it is acknowledged within heterodox economic research, see, e.g. Bush (1987) or Perez (2010). Technological innovation itself demands systematic integration into other societal sub-systems, in order to sustain novel techno-economic paradigms (Perez 2010) as stable configurations. That is also why evolutionary economic analysis of innovation has been rooted in a complex system perspective from its onset. Bettin (2020) demonstrates in this SI how an amended technological innovation system approach can be used to implement parts of the "next phase of energy transition", with a particular focus on electricity infrastructure powered by renewable energies. Today, capitalism faces the challenge of a next phase of energy transition to address ecological crisis. Ecological economists have argued for a long time for better synthesis of societynature relations in political-economic analysis (see Spash 2017). This theoretical development represents an essential process since the corridor of maneuvering out of the ecological crisis is already very narrow and a paradigmatic change is in desperate need.

Bettin (2020) points in this direction by making comprehensive recommendations for an amended innovation system approach. He discusses the realm of energy transitions from the perspective of electricity infrastructures for renewable energies. One of

\footnotetext{
10 "Individual persons or individual companies produce and then see if they can sell their goods on the market" (ibid.)

11 “i.e. ultimately (somehow) communicatively coordinated production” (ibid.)
} 
the central starting points on energy usage and transition is concerned with the material foundations of energy, the infrastructure and its physical presence on the planet. Fossil energy usually comes with a centrally organized infrastructure and electricity net, whereas renewable energies demand a decentralized organized infrastructure and corresponding electricity nets. However, such infrastructure requires flexible solutions, such as, e.g. energy storages. Bettin (2020) highlights that an innovation system approach for renewable energy infrastructure needs to be evolutionary, because it relies on concepts such as historicity, irreversibility, path-dependence and contingency. Concepts are crucial for understanding evolution and complexity in political economy. Innovation systems are developing historically and spatially over many decades, sometimes hundreds of years. Their longevity depends more on the planning horizon of the national economy than on the market mechanism, as the author outlines with reference to List (1841). ${ }^{12}$ That is why Bettin (2020) suggests transforming the current energy system to a multi-level perspective ${ }^{13}$ on the scale of policy. Radical changes need niches to prosper.

For example, Schumpeterian patterns can be observed, where new firms with new technologies compete with incumbent ones. Conversely, substitution within sustainable socio-technical also transition happens through other channels: e.g., outsiders such as activists, and other citizens develop and deploy technologies based on normative rationales.

Bettin (2020)

This is one particular niche of change where the continuities may get disrupted by discrete shifts in the evolution of political economy, where the technical imaginary may also gain social momentum, leading to something novel. Bettin (2020) lays out a clear recipe for amending the components of the technological innovation system approach, to make the energy transformation to a low-carbon society successful. The framework builds on the following amendments to the technological innovation system (TIS) framework and picks up several ideas from research in evolutionary political economy and ecological economics: "(1) Inclusion of physical-structure/ nature as a fifth element of TIS, next to actors, networks, institutions, and technologies. (2) Capturing complex diffusion dynamics in markets in TIS by including social acceptance. (3) Incorporating the wider political economy of power relations and capitalism in TIS" (Bettin 2020, pp. 24-27).

The contributions discussed above highlight the interdependence of communication, complexity, technology and social-ecological metabolism in the evolution of contemporary capitalism. These focus on recent developments in automation and the energy sources of the accumulation process. In the following, we discuss one new configuration and relocate the evolution of political economy in the context of one of its main drivers: the labor process.

\footnotetext{
${ }^{12}$ Compare evolutionary institutionalist approaches to the question how different species of institutions and corporations shape the "course of national economic development", e.g. Galbraith (1967) and Gruchy (1973).

${ }^{13}$ Compare Geels (2002) for the original multi-level perspective and Foxon (2011) for a co-evolutionary approach.
} 


\section{Summary and editorial reflections II: platform-mediated work as a locus of clashes}

Conceptualized in simple, dry, uninformed and de-contextualized manner, platforms are too often seen as providers of socio-technical infrastructures and digital market organizers. They are said to facilitate digitally mediated interactions between buyers and sellers of goods and services in various economy domains, usually relying on an indirect employment or contract relation with the latter (Kenney and Zysman 2016; Kirchner and Schüßler 2019). Platform capitalism literature extends that (see, e.g. Langley and Leyshon 2017, Montalban et al. 2019, Srnicek 2017) and places platforms among actors within a capitalist mode of production - thirsty for "profit, new markets, new commodities and new means of exploitation" (Srnicek 2017, p. 3), building on network effects towards monopolization (Pagano 2014). As intermediators of market encounters in digital space (Çalişkan and Callon 2010), platforms simultaneously coordinate multi-sided connections and the effects thereof (Langley and Leyshon 2017; van Dijck et al. 2018). As actors in processes of capitalization, platform business models heavily rely on venture capital and strengthen the premise of "leveraging debt against future revenue prospects from digital economic circulation" (Langley and Leyshon 2017, p. 13), becoming "rentiers of the network" (O'Dwyer 2015, p. 234). Through the intense datafication and commodification mechanisms, platforms ultimately blur a range of boundaries: for example, between for- and non-profit, free and paid for, private and public (van Dijck et al. 2018). Finally, they fuzz various distinctions pertinent to the employment relationships (Mair and Reischauer 2017; Srnicek 2017; Wood et al. 2018), redefining who is seen as an employee and who as a worker (Vercellone 2007).

Which brings us to the pivotal role of platforms in the ongoing multi-faceted processes of reshaping of labor. Attempts of understanding platform-mediated work are proliferating, building a body of heterogeneous contributions that differ in terms of defining the scope of platform-mediated work. Digital labor, for example, is a term that has been often used by critical algorithm and media scholars (Duffy and Schwartz 2018; Gillespie 2010, 2015, 2017; Kelkar 2018; Ruckenstein and Turunen 2019). These denote an understanding akin to a cognitive capitalist reading, where platforms are the center stage for extending the spheres of surplus value extraction to everyday leisure activities (Scholz 2012; Terranova 2000). The term digital labor has also been used to refer, e.g. solely to work arrangements which are transacted and delivered online via the platform (Bergvall-Kåreborn and Howcroft 2014; Huws 2014; Irani 2015), and contrasted with remotely delivered gig work (Healy et al. 2020; Kässi and Lehdonvirta 2016; de Ruyter and Brown 2019; Wood et al. 2019). Those seemingly distant takes on only one term used in regard to platform-mediated work show how platforms render the "problem of labor as at once a commodity and a lived experience" (van Doorn 2017, p. 899), ultimately bringing us back to the problem of social subjection.

The following remarks on platform-mediated work pertain to digitally mediated service work, rather than work performed on social media platforms, commercial retail platforms or common-based peer production sites. As such, we consider in particular income-generating work performed by (private) individuals - the on-demand workforce - and draw the scope of the phenomenon as (a) location-based (offline) 
and web-based (online) platform-mediated work, both types provided by (b) individuals and the crowd (Schmidt 2017). Though still elusive in numbers, platform-mediated work has been estimated to grow at an annual rate of 26\% (Kässi and Lehdonvirta 2016), catering for 1-3\% of all paid work in advanced economies (Healy et al. 2020; Schwellnus et al. 2019), with 70 million workers registered on platforms facilitating only location-based work (Heeks 2017).

Within this heterogeneity of forms that platform-mediated work can take, certain commonalities can be identified, which are crucial for a more "practical-grounding" of the discussion of the contemporary evolution(s) of capitalism(s) in this SI. These overarching issues include, first, flexibilization and individualization of work, rooted in governance of platforms (Gorwa 2019; Montalban et al. 2019) and referring to, but not limited to, the employment question. And, second, the complex practices of algorithmic management and control, or the governance by platforms (ibid.), manifested, e.g. in platform review and rating systems, worker online profiles and various tools of controlling user behavior, which we ultimately link to the issues of appearance, invisibility and user power. Both areas are integral to platform datafication and commodification processes.

Many platform-based companies reshuffle the boundaries between (full) employment and casual or gig labor, highlighting the spatially unfixed character of platformmediated work and its ability to seemingly transcend the local labor markets (Graham et al. 2017a, b), or to simply notoriously misclassify workers. This has been discussed in a range of narratives: from the benefits of flexible work arrangements, e.g. in terms of work schedules (Chen 2018; Huws et al. 2017; Sundararajan 2016), through bridging flexibilization with precarization of work (Aroles et al. 2019; Richardson 2015; Scholz 2016). The narrative of revamped outsourcing has also been present (Callaway 2016; Risak and Lutz 2017; van Doorn 2017), of the deepening of the individuality and fragmentation of work, and a radical responsibilization of the workforce (Cherry 2016; Fleming 2017; Rogers 2015). The question of individualization comes back in face of high specializations of work tasks and standardization of goods and services as another characteristic of platform-mediated work (Frenken and Schor 2017; Langley and Leyshon 2017). The high specialization and standardization stabilize the expectations of the users and are, therefore, central to the pricing process.

In a regulationist reading, flexibilization of the wage-labor nexus, outsourcing and individualization are the key neoliberal trends boosted by platforms (Montalban et al. 2019), ultimately contributing to further disempowerment of the platform workers. Collective organization of platform workers is mostly addressed and rather critically assessed within web-based crowd work (Gegenhuber et al. 2018; Graham and Woodcock 2018). Here, flexibility of platform-mediated work is also seen as a barrier to effective worker organization, drawing attention to platforms as "stages" for fostering freelancer and entrepreneurial identities (Wood et al. 2018). This platform-enabled "independence" also translates into low institutional visibility of big parts of ondemand workforce, with many platform workers balancing on the thin line between formality and informality of employment, and platforms often incentivising registration of workers by themselves or by the clients, yet failing to supervise the execution thereof (Ticona and Mateescu 2018; van Doorn 2017, 2020). Platforms are therefore positioned as mediators of dualization of labor markets, increasing the risks of exacerbating existing inequalities (Greve 2019). As such, the "be your own boss" and "make extra 
cash easy" rhetoric might be valid for some platform workers. For others, especially those who are, due to various grounds, already in precarious conditions, vulnerable and unprotected, platform-mediated work might simultaneously be the last resort for getting work and a dead end for decent work.

Our second area of interest in the ongoing platform-mediated transformation of labor moves on to governance by platforms (Greve 2019; van Dijck et al. 2018), more commonly referred to as algorithmic governance/management/control. Just like other modern organizations, platforms follow "an institutional data imperative" (Fourcade and Healy 2017 , p. 9). In the case of platforms, data is generated by their users' inputs, and their activities, facilitated with a digital interface. These are subject to various review, rating and scoring systems, which results in constant monitoring, tracking and evaluation (Bratton 2015; Fourcade and Healy 2017; Langley and Leyshon 2017; Pasquale 2015, 2018). Algorithmic techniques of working with large volumes of quantitative data have led to the emergence of a new regime of moralized social classification fed by the "twin process of big data-based valuation (of individuals) and value extraction (from individuals)" (Fourcade and Healy 2017, p. 10), spanning both material and symbolic dimensions, being both market-derived and marketoriented.

Platform review and ratings systems, as well as online profiles of different users, verification tools or measuring worker performance via other factors like the responsiveness rate in communication with potential clients, are strongly related to the reduced transaction costs and the ways in which platforms facilitate trust building. The efficacy of such reputation metrics is carefully designed and built into platform infrastructures, and used as stimulants of high quality of services delivered via the platform, but also as drivers of specific user behaviors, and "ways-around" uncomfortable regulations (Marwick 2013; Rieder 2016; van Dijck et al. 2018). For platform workers, algorithmically controlled work means navigating through "the digital" in a skillful, informed manner, oftentimes based on scattered information, in order to cater for their individual (online and offline) visibility (Gruszka and Böhm 2020; Ticona and Mateescu 2018; van Doorn 2017). It is a situation of being stretched between surveillance and self-regulation (Shapiro 2018; Wood et al. 2019).

The plurality of the ways in which this process looks like for platform workers, and how it is experienced by them, is astonishing, and is still under-conceptualized and rather scattered (Cherry 2016; Irani 2015; Ticona and Mateescu 2018). The existing studies do show, however, that virtually every platform worker puts considerable effort into a careful orchestration of their "online selves"- be it a provider of the service off or on the platform, be it a selected individual providing the service, or a crowdworker. For example, Turkers - micro-working on Amazon's Mechanical Turk (AMT) - are seen by requesters as a string of numbers ID, with a range of performance stats on the efficiency of their labor rendered on the basis of, e.g. their acceptance rate and time needed for each task, and a consequent worker rating. The bodilessness of crowdworkers is extensively explored by, e.g. Irani (2015) and Cherry (2016), who jointly see platform-specific design as a means of hiding platform workers (via, e.g. online profiles, avatars, IDs), essentially begging the question whether it is individuals or rather well-trained algorithms performing the tasks. Turkers might also boost their score by completing educational trainings offered by AMT, or trick the system and, e.g. manipulate the information provided on their geographical location in order to access 
better-paid tasks from requesters who exclude offers from Turkers in particular regions of the world (Graham et al. 2017a, b; Wood et al. 2019). Location-based individual platform workers are in yet another context. Their efforts on reaching and maintaining a high rating are quite complex and involve for example invisible work put into crafted personal narratives in online profiles of platform care-workers, carefully selected identity verification tools for workers in largely informal sectors, or Uber drivers keeping their manners and spirits up during the rides and their cars tidy. However, doing the job well, to put it simply, is not enough in many cases, since platforms offer additional paid options for manipulating the transparency of those trust-enabling mechanisms, which prioritize certain workers over others in the search results. Algorithmic management and other platform-inherent worker control mechanisms, thus, are often a competitive area in which workers both "negotiate the engineering of their visibility, agency, and income opportunities" (van Doorn 2020, p. 2).

A thus far most interesting discussion of the ways in which platforms affecting labor and control the workforce is developed by Van Doorn (2017). Exploring particularly the question of how platforms exacerbate the precarity of the most vulnerable workers, three platform-specific mechanisms are identified: (i) bolstering the immunity of platform intermediaries and clients, (ii) expanding managerial control over workers and (iii) rendering the platform workforce as fungible and superfluous. The two core areas problematized above in our discussion of platformmediated work resurface in each of the mechanisms and their intersectional dynamics. The blurry (or flexible) employment relations guarantee a safe and protected ground for platforms and the users on the demand side, since worker misclassification practices and platform terms of service agreements in practice often eliminate the obligations pertaining to an employment relationship, despite the occurrence of employment situation. This occurrence necessarily includes the presence of control over workers, which platforms exert through various (more or less opaque) techniques of algorithmic management. Crucially, information asymmetries in, e.g. platform review and rating systems or the different user-type-dependent verification procedures, seem to be "the normal" for platforms mediating work, further boosting their immunity and this of the clients/requesters/bookers (van Doorn 2017). Thus, the radicalization of worker responsibility contributes to the immunity of platforms also through a direct link to the algorithmic tools employed for dictating the conditions of an employment situation. Finally, the fungibility and superfluity of workers are algorithmically managed in a way that creates an impression of an almost inexhaustible pool of on-demand workforce, often within reach around the globe. These data-driven techniques of socio-technical obfuscation essentially conceal the workers from view, fueling the naïve narratives of their happy, independent and flexible work life, and concealing the "gendered, racialized, and classed distribution of opportunities and vulnerabilities associated with [it]" (van Doorn 2017, p. 898, see also 2020).

The control and power over the labor process have thus undergone substantial shifts in the last decade. Platform-mediated forms of employment are proliferating and will further commodify various spheres of life and labor. The precondition for that has been set by slow processes of shifting exploitation from real subsumption to the "subsumption of the general intellect" of the labor process, as discussed in the concluding section. 


\section{Back to the planetary carambolage: platforms, subsumption and contemporary capitalism}

The evolution of power relations has always been central for the analysis of capitalist development, as we have already highlighted with reference to the interplay of the political and the economic sphere and the aspect of group communication and hegemony. Capitalism has quite logically made its most significant transformations in those periods when the power relations have changed on global scale. This was always the case after a final financial expansion of the various accumulation cycles, as we have already outlined with reference to Arrighi and Moore (2001). But it was not just the shift in global power that is associated with major transformations, it is also the shift of hegemony in the production process. As it was typical for classical political economy, Marx (1992) also explored the transformation from merchant to industrial capitalism. His analysis was unique and innovative, because he discussed this process along a change in the subsumption of labor under capital and, more explicitly, in the corresponding change of surplus value extraction. Following Marx, the extraction of absolute surplus value requires a formal subsumption of labor under capital in the mode of production, whereas relative surplus value is achieved from real subsumption.

The production of absolute surplus-value turns exclusively on the length of the working day, whereas the production of relative surplus value completely revolutionizes the technical processes of labor and the groupings into which society is divided. It therefore requires a specifically capitalist mode of production, a mode of production which, along with its methods, means and conditions, arises and develops spontaneously on the basis of the formal subsumption of labor under capital. This formal subsumption is then replaced by a real subsumption.

Marx 1992, p. 645)

The latter emerges - “develops spontaneously"- through the metamorphosis from merchant to industrial capitalism and accelerates capitalist expansion tremendously. The development of ever more specialized large-scale industrial machinery and its use in capitalist production processes fostered the (still ongoing) fragmentation of labor processes into ever more tiny subroutines. ${ }^{14}$ This has not just led to a loss of hegemony for the working class, since their knowledge and skills became easier to substitute, in comparison to the more universal craftsmen of merchant capitalism. ${ }^{15}$ The new productivity gains made through technological change enabled, on the one hand, to upscale mass production and circulation of commodities as well capital and, on the other hand, to make production ever more compartmentalized in fragmented subroutines. It is the latter process that buries the hegemony of craftsmanship and accelerates alienation.

This raises the question about the existence of a second major transformation in capitalist development in context of planetary carambolage, based on the real

\footnotetext{
${ }^{14}$ This is evident through the stagewise evolutionary development of this fragmentation of labor processes. Starting with Taylorism and Fordism, eventually finding a new peak in platform-mediated work as we have outlined.

${ }^{15}$ Compare Vercellone (2007) and the role of knowledge and power in subsumption conflicts about hegemony.
} 
subsumption of labor under capital. Scholars have brought forward the hypothesis of a transition from industrial to "cognitive capitalism" (e.g. Vercellone 2007). This would involve a novel "subsumption of the general intellect", going back to an early hypothesis developed already by Marx in the Grundrisse (Marx 1992, pp. 690-712). The general intellect is a metaphor for social knowledge broadly conceived, including public education, skills, and technical expertise in the labor force. It is represented in the development of fixed capital in production that would not have been possible without a progressively increasing social and public knowledge base. Therefore, it is on the one hand a product of the exploitation of workers in crafting ever better machinery and on the other hand a potential source of social emancipation (Vercellone 2007).

Today, in the light of the platform economy, the subsumption of the general intellect implies firstly the harvest of individually generated data, ${ }^{16}$ sold to the advertisement industry that is able to personalize and target ads in order to extract a novel source of surplus. Secondly, the intensified precarization and flexibilization through platform work allows the generation of additional surplus. Both processes can get further associated with the rise of intellectual monopoly capitalism (Pagano 2014), which could serve as another indicator to confirm this transition to cognitive capitalism. Vercellone (2007) argues that this process also shows characteristics for a potential social emancipation of the working class through open knowledge, the development of the commons and the collective use of the general intellect. However, this point finds also critique (see, e.g. Pitts 2017), because it may overestimate the potential of the sublation of the law of labor value (resting on a productivist view), if not compensated by a larger critical emancipatory process of social mediation as argued by Fuchs (2020) and Schröter (2020).

Platform-mediated work, as shown in the previous section, provides a fertile area for further understanding of not only the problem of labor as commodity and a lived experience (van Doorn 2017), but rather the full integration of the political and economic sphere. The emergent biopolitics of platforms simultaneously caters for what platform-mediated work literature refers to as governance of and by platforms. These mechanisms of control make a potential collective emancipation of the platformmediated working class not only difficult, but very unlikely in near future. The radical responsibilization of the more and more flexible and individualized workforce and the mechanisms of rendering platform workers superfluous and easily replaceable correspond to the evolving labor exploitation. Platform algorithmic management and control practices embody dividuation, where workers on the one hand engage in meticulous crafting of self-narratives and "digital appearance" with the available digital spaces and tools, and, on the other hand, themselves and their work are subject to refined modes of surveillance. As a result, the data-driven "platform environment" is cohabited by control, algorithmically boosted competition, fear, panic and burn-out, further challenging the ongoing transformations of labor, in particular workers' visibility, power and existence.

Planetary carambolage shows that capitalist exploitation processes collide and intermingle with each other on planetary scale. They are likely to tip over into catastrophes, and, therefore, deserve close inspection. This article emphasizes the need for an integrated and systematic approach in analysing the relations between

\footnotetext{
${ }^{16}$ Possible only through the progressive development of a literate and digital-savvy public.
} 
technology, nature and work. The contributions to this SI indicate how a transdisciplinary evolutionary political economy approach can contribute to more insight into the variety and interdependence of problems emerging from the planetary carambolage. The transdisciplinary project we have in mind is clearly committed to the search for "a new configuration that allows for an overall lower, more progressive, entropy level." (Hanappi 2020). Such a new stable configuration depends on the way we reorganize and coordinate the social-ecological metabolism with human work as its catalyst and medium between society and nature.

Funding Open access funding provided by Vienna University of Economics and Business (WU).

Open Access This article is licensed under a Creative Commons Attribution 4.0 International License, which permits use, sharing, adaptation, distribution and reproduction in any medium or format, as long as you give appropriate credit to the original author(s) and the source, provide a link to the Creative Commons licence, and indicate if changes were made. The images or other third party material in this article are included in the article's Creative Commons licence, unless indicated otherwise in a credit line to the material. If material is not included in the article's Creative Commons licence and your intended use is not permitted by statutory regulation or exceeds the permitted use, you will need to obtain permission directly from the copyright holder. To view a copy of this licence, visit http://creativecommons.org/licenses/by/4.0/.

\section{References}

Aigner E, Scholz-Wäckerle M (2019) On the possibility of a society after money: evolutionary political economy, economic subjectivity and planetary-scale computation. In: Dialogue A (ed) Society After Money, Project society after money. Bloomsbury Academic, New York, pp 181-205

Aroles J, Mitev N, de Vaujany FX (2019) Mapping themes in the study of new work practices. N Technol Work Employ 34(3):285-299. https://doi.org/10.1111/ntwe.12146

Arrighi G, Moore JW (2001) Capitalist development in world historical perspective. In: Albritton R, Itoh M, Westra R, Zuege A (eds) Phases of capitalist development. Palgrave Macmillan, London

Arthur WB (2009) The nature of technology: what it is and how it evolves. Simon and Schuster, New York

Baran PA, Sweezy PM (1977) Monopoly capital: an essay on the American economic and social order. Penguin Books, London

Bergvall-Kåreborn B, Howcroft D (2014) Amazon Mechanical Turk and the commodification of labour. N Technol Work Employ 29(3):213-223. https://doi.org/10.1111/ntwe.12038

Bertani F, Raberto M, Teglio A (2020) The productivity and unemployment effects of the digital transformation: an empirical and modelling assessment. Rev Evol Polit Econ 3:XX-XX

Bettin S (2020) Electricity infrastructure and innovation in the next phase of energy transition - amendments to the technology innovation system framework. Rev Evol Polit Econ 3:XX-XX

Bratton BH (2015) The stack. On Software and Sovereignty. MIT Press, Cambridge, Massachusets

Brennan DM, Kristkanson-Gural D, Mulder CP, Olsen EK (eds) (2017) The Routledge Handbook of Marxian Economics. Routledge, Abingdon and New York

Bush PD (1987) The theory of institutional change. J Econ Issues 21(3):1075-1116

Butchart SHM, Walpole M, Collen B, van Strien A, Scharlemann JPW, Almond REA, Baillie JEM, Bomhard B, Brown C, Bruno J, Carpenter KE, Carr GM, Chanson J, Chenery AM, Csirke J, Davidson NC, Dentener F, Foster M, Galli A, Galloway JN, Genovesi P, Gregory RD, Hockings M, Kapos V, Lamarque J-F, Leverington F, Loh J, McGeoch MA, McRae L, Minasyan A, Morcillo MH, Oldfield TEE, Pauly D, Quader S, Revenga C, Sauer JR, Skolnik B, Spear D, Stanwell-Smith D, Stuart SN, Symes A, Tierney M, Tyrrell TD, Vié J-C, Watson R (2010) Global biodiversity: indicators of recent declines. Science (New York, NY) 328(5982):1164-1168. https://doi.org/10.1126/science.1187512

Çalişkan K, Callon M (2010) Economization, part 2: a research programme for the study of markets. Econ Soc 39(1):1-32. https://doi.org/10.1080/03085140903424519 
Callaway A (2016) Apploitation in a city of instaserfs: how the "sharing economy" has turned San Francisco into a dystopia for the working class. The Monitor. Retrieved from: https:/www.policyalternatives.ca/ publications/monitor/apploitation-city-instaserfs. Accessed 10 Apr 2020

Chen JY (2018) Thrown under the bus and outrunning it! The logic of Didi and taxi drivers' labour and activism in the on-demand economy. New Media Soc 20(8):2691-2711. https://doi.org/10.1177/ 1461444817729149

Cherry M (2016) Virtual work and invisible labour. In: Crain MG, Poster W, Cherry M (eds) Invisible labour: hidden work in the contemporary world. University of California Press, Oakland, pp 71-86

Deleuze G (1992) Postscript on the Societies of Control, October 59:3-7. Accessed 04 May 2020

de Ruyter A, Brown M (2019) The gig economy. Columbia University Press, New York City

Dopfer K (2004) The economic agent as rule maker and rule user: Homo Sapiens Oeconomicus. J Evol Econ 14:177-195. https://doi.org/10.1007/s00191-004-0189-9

Dopfer K, Foster J, Potts J (2004) Micro-meso-macro. J Evol Econ 14(3):263-279

Dosi G, Roventini A (2019) More is different ... and complex! The case for agent-based macroeconomics. J Evol Econ 29:1-37. https://doi.org/10.1007/s00191-019-00609-y

Duffy BE, Schwartz B (2018) Digital “women's work?" job recruitment ads and the feminization of social media employment. New Media Soc 20(8):2972-2989. https://doi.org/10.1177/1461444817738237

Elsner W (2017) Complexity economics as heterodoxy: theory and policy. J Econ Issues 51(4):939-978. https://doi.org/10.1080/00213624.2017.1391570

Elsner W, Heinrich T (2009) A simple theory of 'meso'. On the co-evolution of institutions and platform size - with an application to varieties of capitalism and 'medium-sized' countries. J Socio-Econ 38(5): 843-858

Eversberg D (2014) Dividuell aktiviert. Wie Arbeitsmarktpolitik Subjektivitäten produziert. Campus, Frankfurt/New York

Fine B (2001) Social capital versus social theory. Routledge, London and New York

Fischer-Kowalski M (1998) Society's metabolism. The intellectual history of materials flow analysis, part I, 1860-1970. J Ind Ecol 2(1):61-78. https://doi.org/10.1162/jiec.1998.2.1.61

Fleming P (2017) The human capital hoax: work, debt and insecurity in the era of Uberization. Organ Stud 38(5):691-709. https://doi.org/10.1177/0170840616686129

Foley DK (2020a) Socialist alternatives to capitalism I: Marx to Hayek, Review of Evolutionary Political Economy. 3:XX-XX. https://doi.org/10.1007/s43253-020-00012-5

Foley D (2020b) Socialist alternatives to capitalism II: Vienna to Santa Fe. Rev Evol Polit Econ 3:XX-XX. https://doi.org/10.1007/s43253-020-00013-4

Foster J (1999) Marx's theory of metabolic rift: classical foundations for environmental sociology. Am J Sociol 105(2):366-405. https://doi.org/10.1086/210315

Foster JB (2013) The fossil fuels war. Mon Rev 65(4):1. https://doi.org/10.14452/MR-065-04-2013-08_1

Fourcade M, Healy K (2017) Seeing like a market. Soc Econ Rev 15(1):9-29. https://doi.org/10.1093/ser/ mww033

Foxon TJ (2011) A coevolutionary framework for analysing a transition to a sustainable low carbon economy. Ecol Econ 70:2258-2267. https://doi.org/10.1016/j.ecolecon.2011.07.014

Frenken K, Schor J (2017) Putting the sharing economy into perspective. Environ Innov Soc Transit 23:3-10. https://doi.org/10.1016/j.eist.2017.01.003

Fuchs C (2020) Communication and capitalism: a critical theory. University of Westminster Press, London

Galbraith JK (1967) The new industrial state. Princeton University Press, Princeton

Geels FW (2002) Technological transitions as evolutionary reconfiguration processes: a multi-level perspective and a case-study. Res Policy 31:1257-1274. https://doi.org/10.1016/S0048-7333(02)00062-8

Gegenhuber T, Ellmer M, Scheba C (2018) Partizipation von CrowdworkerInnen auf CrowdsourcingPlattformen. Bestandsaufnahme und Ausblick. HBS Study No. 391. Düsseldorf. Accessed 04 May 2020

Georgescu-Roegen N (1971) The entropy law and the economic process. Harvard University Press, Cambridge (MA)

Gillespie T (2010) The politics of "platforms". New Media Soc 12(3):347-364. https://doi.org/10.1177/ 1461444809342738

Gillespie T (2015) Platforms intervene. Social Media + Society. April-June: 1-2. https://doi.org/10.1177/ 2056305115580479

Gillespie T (2017) Regulation of and by platforms. In: The SAGE Handbook of Social Media. SAGE Publications Ltd., pp 254-278. https://doi.org/10.4135/9781473984066.n15

Gorwa R (2019) What is platform governance? Inf Commun Soc 22(6):854-871. https://doi.org/10.1080/ 1369118X.2019.1573914 
Graham M, Woodcock J (2018) Towards a fairer platform economy: introducing the Fairwork Foundation. Altern Routes 29:242-253

Graham M, Hjorth I, Lehdonvirta V (2017a) Digital labour and development: impacts of global digital labour platforms and the gig economy on worker livelihoods. Transfer 23(2):135-162. https://doi.org/10.1177/ 1024258916687250

Graham M, Lehdonvirta V, Wood A, Barnard H, Hjorth I, Simon DP (2017b) The risks and rewards of online gig work at the global margins, pp 1-13. Retrieved from: https://www.oii.ox.ac.uk/publications/gigwork. pdf. Accessed 04 May 2020

Greve B (2019) The digital economy and the future of European welfare states. Int Soc Secur Rev 72(3):7994. https://doi.org/10.1111/issr.12214

Gruchy AG (1973) Law, politics, and institutional economics. J Econ Issues 7(4):623-643

Gruszka K, Böhm M (2020) Out of sight, out of mind? (In)visibility of/in platform-mediated work. New Media Soc X:XX-XX. https://doi.org/10.1177/1461444820977209 ID: NMS-20-0830.R2

Haberl H, Wiedenhofer D, Virág D, Kalt G, Plank B, Brockway P, Fishman T, Hausknost D, Krausmann F, Leon-Gruchalski B, Mayer A, Pichler M, Schaffartzik A, Sousa T, Streeck J, Creutzig F (2020) A systematic review of the evidence on decoupling of GDP, resource use and GHG emissions, part II: synthesizing the insights. Environ Res Lett 15(6):065003. https://doi.org/10.1088/1748-9326/ab842a

Hanappi H, Scholz-Wäckerle M (2017) Evolutionary political economy: content and methods. Forum Soc Econ. https://doi.org/10.1080/07360932.2017.1287748

Hanappi H (2020) Perplexing complexity. Human modelling and primacy of the group as essence of complexity. Rev Evol Polit Econ 3:XX-XX

Healy J, Pekarek A, Vromen A (2020) Sceptics or supporters? Consumers' views of work in the gig economy. N Technol Work Employ 35(1):1-19. https://doi.org/10.1111/ntwe.12157

Heeks R (2017) Decent work and the digital gig economy: a developing country perspective on employment impacts and standards in online outsourcing, crowdwork, etc. Development Informatics Working Paper no. 7, Manchester. Retrieved from: http://hummedia.manchester.ac.uk/institutes/gdi/publications/ workingpapers/di/di_wp71.pdf. Accessed 15 Nov 2020

Hornborg A (2016) Global magic: technologies of appropriation from ancient Rome to Wall Street. Palgrave Macmillan US, New York

Huws U (2014) Labour in the global digital economy. Monthly Review Press, New York

Huws U, Spencer NH, Syrdal DS, Holts K (2017) Work in the European Gig Economy: research results from the UK, Sweden, Germany, Austria, the Netherlands, Switzerland and Italy. FEPS - Foundation For European Progressive Studies: Brussels. Retrieved from: https://uhra.herts.ac.uk/bitstream/handle/2299/ 19922/Huws_U._Spencer_N.H._Syrdal_D.S._Holt_K._2017_.pdf?sequence=2. Accessed 15 Nov 2020

IPCC (2012) Managing the risks of extreme events and disasters to advance climatechange adaptation. In: Field CB, Barros V, Stocker TF, Qin D, Dokken DJ, Ebi KL, Mastrandrea MD, Mach KJ, Plattner G-K, Allen SK, Tignor M, Midgley PM (eds) A special report of working groups I and II of the Intergovernmental Panel on Climate Change. Cambridge University Press, Cambridge and New York, pp 582

Irani L (2015) The cultural work of microwork. New Media Soc 17(5):720-739. https://doi.org/10.1177/ 1461444813511926

Jo T-H, Chester L, D’Ippoliti C (eds) (2018) The Routledge handbook of heterodox economics. Theorizing, analyzing, and transforming capitalism. Routledge, Abingdon and New York

Kässi O, Lehdonvirta V (2016) Online labour index: measuring the online gig economy for policy and research. In: Internet, politics \& policy. Oxford. Retrieved from https://mpra.ub.uni-muenchen.de/74943/ 1/MPRA_paper_74943.pdf. Accessed 05 May 2020

Kelkar S (2018) Engineering a platform: the construction of interfaces, users, organizational roles, and the division of labour. New Media Soc 20(7):2629-2646. https://doi.org/10.1177/1461444817728682

Kenney M, Zysman J (2016) The rise of the platform economy. Issues Sci Technol 32(3):61-69

Kirchner S, Schüßler E (2019) The organization of digital marketplaces. In: Ahrne G, Brunsson N (eds) Organization unbound. Cambridge University Press, London, pp 131-154

Langley P, Leyshon A (2017) Platform capitalism: the intermediation and capitalization of digital economic circulation. Finance Soc 3(1):11-31. https://doi.org/10.2218/finsoc.v3i1.1936

Lazaratto M (2014) Signs and machines. Capitalism and the production of subjectivity. MIT Press, Cambridge, Massachusetts

Likavčan L, Scholz-Wäckerle M (2018) Technology appropriation in a de-growing economy. J Clean Prod 197(2):1666-1675. https://doi.org/10.1016/j.jclepro.2016.12.134

List F (1841) Das nationale System der politischen Ökonomie. JG Cotta, Stuttgart 
Mair J, Reischauer G (2017) Capturing the dynamics of the sharing economy: institutional research on the plural forms and practices of sharing economy organizations. Technol Forecast Soc Chang 125:11-20. https://doi.org/10.1016/j.techfore.2017.05.023

Malm A (2013) The origins of fossil capital: from water to steam in the British cotton industry. Hist Mater 21(1):15-68. https://doi.org/10.1163/1569206X-12341279

Marwick AE (2013) Status update: celebrity, publicity, and branding in the social media age. Yale University Press, New Haven

Marx K (1992) Capital. In: A critique of political economy, vol I. Penguin Books in association with New Left Review, London and New York

Montalban M, Frigant V, Jullien B (2019) Platform economy as a new form of capitalism: a Régulationist research programme. Camb J Econ 43:805-824. https://doi.org/10.1093/cje/bez017

O’Dwyer R (2015) Money talks: the enclosure of mobile payments. In: Loving G, Tkacz N, de Vries P (eds) MoneyLab reader: an intervention in digital economy. Institute of Network Cultures, Amsterdam, pp $230-244$

Pagano U (2014) The crisis of intellectual monopoly capitalism. Camb J Econ 38:1409-1429

Pasquale F (2015) The other big brother. The Atlantic Retrieved from https:/www.theatlantic.com/business/ archive/2015/09/corporate-surveillance-activists/406201/. Accessed 10 May 2020

Pasquale F (2018) Tech platforms and the knowledge problem. Retrieved from https://americanaffairsjournal. org/2018/05/tech-platforms-and-the-knowledge-problem/. Accessed 10 May 2020

Perez C (2010) Technological revolutions and techno-economic paradigms. Camb J Econ 34:185-202. https:// doi.org/10.1093/cje/bep051

Pitts FH (2017) Beyond the fragment: postoperaismo, postcapitalism and Marx's 'notes on machines', 45 years on. Econ Soc 46(3-4):324-345. https://doi.org/10.1080/03085147.2017.1397360

Prigogine I, Stengers I (1997) The end of certainty. Simon and Schuster, New York

Rengs B, Scholz-Wäckerle M (2019) Consumption \& class in evolutionary macroeconomics. J Evol Econ 29: 229-263. https://doi.org/10.1007/s00191-018-0592-2

Richardson L (2015) Performing the sharing economy. Geoforum 67:121-129. https://oi.org/10.1016/j. geoforum.2015.11.004

Richerson PJ, Boyd R (2010) Why possibly language evolved. Biolinguistics 4(2-3):289-306

Rieder B (2016) Big data and the paradox of diversity. Digit Cult Soc 2(2):39-54. https://doi.org/10.14361/ dcs-2016-0204

Risak M, Lutz D (2017) Arbeiten in der Gig-Economy. ÖGB-Verlag, Wien

Rogers B (2015) Employment rights in the platform economy: getting back to basics. Harv Law Policy Rev 10:479-520. https://doi.org/10.2139/ssrn.2641305

Ruckenstein M, Turunen LLM (2019) Re-humanizing the platform: content moderators and the logic of care. New Media Soc 22:1026-1042. https://doi.org/10.1177/1461444819875990

Sassen S (2014) Expulsions: brutality and complexity in the global economy. Harvard University Press, Cambridge

Scheidel A, Del Bene D, Liu J, Navas G, Mingorría S, Demaria F, Avila S, Roy B, Ertör I, Temper L, Martínez-Alier J (2020) Environmental conflicts and defenders: a global overview. Glob Environ Chang 63:102104. https://doi.org/10.1016/j.gloenvcha.2020.102104

Schmidt FA (2017) Digital labour markets in the platform economy. Division for Economic and Social Policy, pp 1-30. Retrieved from www.fes-2017plus.de. Accessed 04 May 2020

Scholz T (2012) Digital labour: the internet as playground and factory. Routledge, London

Scholz T (2016) Uberworked and underpaid: how workers are disrupting the digital economy. Polity, Cambridge

Scholz-Wäckerle M (2017) Generating meso behavior. Routledge International Handbook of Behavioral Economics. Routledge, London and New York

Schröter J (2020) Imaginary economies: the case of the 3D printer. Rev Evol Polit Econ 3:XX-XX. https://doi. org/10.1007/s43253-020-00014-3

Schwellnus C, Geva A, Pak M, Veiel R (2019) Gig economy platforms: boon or bane ? OECD Economics Department Working Papers No. 1550. https://doi.org/10.1787/fdb0570b-en

Shapiro A (2018) Between autonomy and control: strategies of arbitrage in the "on-demand" economy. New Media Soc 20(8):2954-2971. https://doi.org/10.1177/1461444817738236

Spash CL (ed) (2017) Routledge handbook of ecological economics. Nature and Society. Routledge, Abingdon and New York

Srnicek N (2017) Platform capitalism. Polity, Cambridge, Massachusets

Steffen W, Grinevald J, Crutzen P, McNeill J (2011) The Anthropocene: conceptual and historical perspectives. Phil Trans R Soc A 369:842-867. https://doi.org/10.1098/rsta.2010.0327 
Sundararajan A (2016) The sharing economy: the end of employment and the rise of crowd-based capitalism. MIT Press, Cambridge

Terranova T (2000) Free labour: producing culture for the digital economy. Soc Text 18(2):33-58

Ticona J, Mateescu A (2018) Trusted strangers: carework platforms' cultural entrepreneurship in the ondemand economy. New Media Soc 20(11):4384-4404. https://doi.org/10.1177/1461444818773727

Toporowski J (2020) Financialisation and the periodisation of capitalism: appearances and processes. Rev Evol Polit Econ 1:149-160. https://doi.org/10.1007/s43253-020-00005-4

van Dijck J, Poell T, de Waal M (2018) The platform society: public values in a connective world. Oxford University Press, New York

van Doorn N (2017) Platform labour: on the gendered and racialized exploitation of low-income service work in the 'on-demand' economy. Inf Commun Soc 20(6):898-914. https://doi.org/10.1080/1369118X.2017. 1294194

van Doorn N (2020) Stepping stone or dead end? The ambiguities of platform-mediated domestic work under conditions of austerity urbanism. Retrieved from https://platformlabour.net/output/wp-stepping-stonedead-end-van-doorn. Accessed 04 May 2020

Vercellone C (2007) From formal subsumption to general intellect: elements for a Marxist reading of the thesis of cognitive capitalism. Hist Mater 15(1):13-36. https://doi.org/10.1163/156920607X171681

Wilson DS (2016) Two meanings of complex adaptive systems. In: Complexity and evolution: toward a new synthesis for economics. MIT Press, Cambridge

Wood AJ, Lehdonvirta V, Graham M (2018) Workers of the internet unite? Online freelancer organisation among remote gig economy workers in six Asian and African countries. N Technol Work Employ 33(2): 95-112. https://doi.org/10.1111/ntwe.12112

Wood AJ, Graham M, Lehdonvirta V, Hjorth I (2019) Good gig, bad gig: autonomy and algorithmic control in the global gig economy. Work Employ Soc 33(1):56-75. https://doi.org/10.1177/0950017018785616

Zuboff S (2019) The age of surveillance capitalism: the fight for a human future at the new frontier of power. Public Affairs, New York 